Volume 1, Nomor 2 Oktober 2019

ISSN : 2656-9639 (Cetak)

ISSN : 2684-9046 (Online)

\title{
ANALISIS KEMAMPUAN INDONESIA DALAM MEMBUAT PERJANJIAN INTERNASIONAL MENURUT HUKUM INTERNASIONAL (Studi Kasus Tidak Diratifikasinya Konvensi 1951 dan Protokol 1967)
}

\author{
Desi Yunitasari \\ Mahasiswa S1 Program Studi Ilmu Hukum \\ Jurusan Hukum dan Kewargenegaraan \\ Fakultas Hukum dan Ilmu Sosial \\ Universitas Pendidikan Ganesha
}

\begin{abstract}
Abstrak
Masalah pengungsi sesungguhnya sudah timbul sejak umat manusia mengenal adanya konflik dan peperangan. Indonesia merupakan salah satu negara yang harus berhadapan dengan permasalahan orang asing pencari suaka dan pengungsi yang masuk dan tinggal di wilayah Indonesia. Namun Indonesia belum meratifikasi perjanjian internasional mengenai pengungsi dan pencari suaka yaitu Konvensi Internasional 1951 dan Protokol 1967. Rumusan masalah yang diangkat alasan dan akibat hukum dari belum diratifikasinya Konvensi 1951 dan Protokol 1967 Penelitian ini menggunakan metode yuridis normatif dengan menekankan pada penggunaan sumber data sekunder sebagai acuan utama. Metode pendekatan menggunakan pendekatan perundang-undangan, conceptual approach, case approach, statute approach dan historis. Hasil penelitian didapatkan penyebab Indonesia belum meratifikasi Konvensi 1951 dan Protokol 1967 tersebut terdiri dari beberapa faktor, faktor eksternal seperti ada beberapa pasal dalam Konvensi 1951 yang cukup berat dan sulit dipenuhi oleh pemerintah Indonesia. Sementara faktor internal seperti Ratifikasi Konvensi 1951 dan Protokol 1967 tentunya juga dapat berdampak pada perekonomian Indonesia. Hal ini terkait dengan pembiayaan penanganan pengungsi dan pencari suaka akan sepenuhnya ditanggung oleh Pemerintah. Jika Indonesia meratifikasinya setidaknya Indonesia mendapat beberapa keuntungan seperti pemerintah dapat menentukan sendiri status para pengungsi dan pencari suaka, pemerintah dapat mendapat bantuan dan kerjasama internasional terkait penguatan kapasitas nasional dalam penanganan pengungsi dan pencari suaka serta mencegah para pembonceng (kegiatan pidana seperti human trafficking) yang memiliki motif yang berbeda.
\end{abstract}

Kata Kunci: Ratifikasi, Konvensi 1951, Protokol 1967

\begin{abstract}
The problem of refugees has actually arisen since mankind recognized the existence of conflict and war. Indonesia is one country that has to deal with the problem of foreign asylum seekers and refugees entering and living in Indonesian territory. However, Indonesia has not yet ratified international treaties on refugees and asylum seekers, namely the 1951 International Convention and the 1967 Protocol. Formulation of the problem raised the legal reasons and consequences of the ratification of the 1951 Convention and 1967 Protocol. main. The method of approach uses a statutory approach, conceptual approach, case approach, statute approach and historical. The results of the study found that Indonesia had not ratified the 1951 Convention and the 1967 Protocol consisted of several factors, external factors such as several articles in the 1951 Convention which were quite heavy and difficult to be fulfilled by the Indonesian government. While internal factors such as the Ratification of the 1951 Convention and
\end{abstract}


Volume 1, Nomor 2 Oktober 2019

ISSN : 2656-9639 (Cetak)

ISSN : 2684-9046 (Online)

the 1967 Protocol can certainly also have an impact on the Indonesian economy. This is related to the financing of handling refugees and asylum seekers will be fully borne by the Government. If Indonesia ratifies at least Indonesia gets some benefits such as the government can determine the status of refugees and asylum seekers themselves, the government can get international assistance and cooperation related to strengthening national capacity in handling refugees and asylum seekers and preventing pillion (criminal activities such as human trafficking) that have different motives.

Keywords: Ratification, Convention 1951, Protocol 1967

\section{Latar Belakang}

Masalah pengungsi sesungguhnya sudah timbul sejak umat manusia mengenal adanya konflik dan peperangan. Pada umumnya yang menjadi pengungsi adalah korban dari aksi kekerasan atau mereka yang melarikan diri dari ganasnya perang yang terjadi di wilayah atau di negaranya. Selama berabad-abad masalah pengungsi ini hanya menimbulkan keprihatinan dan belas kasihan tanpa adanya upaya untuk melindungi secara hukum baik status maupun hak-hak para pengungsi yang merupakan korban tindak kekerasan yang harus dilindungi hak-haknya sebagai manusia yang tertindas. Persoalan pengungsi telah ada sejak lebih kurang abad ke-20, yaitu ketika para pengungsi dari Rusia berbondongbondong menuju ke Eropa Barat. Pada umumnya, pengungsian dilakukan karena terjadinya penindasan hak azasi pengungsi di negara mereka. Pada umumnya mereka juga mencari tanah atau negara lain sebagai tempat kediaman barunya yang tentunya jauh dari penindasan hak azasi manusia (Husin;1998). Istilah dan definisi pengungsi (refugee) pertama kali muncul pada waktu Perang Dunia Pertama, yang dianggap sebagai titik kulminasi dari proses pembangunan sebuah bangsa (Peter J.Taylor;2003).

Kegiatan masyarakat internasional dalam menangani urusan pengungsi dimulai tahun 1921 ketika Liga BangsaBangsa (LBB) mengangkat seorang yang bernama Fridtjof Nansen seorang warga Norwegia dan penjelajah benua Afrika sebagai komisaris tinggi untuk pengungsi Rusia di Eropa. Pengungsipengungsi tersebut tidak mempunyai identitas sebagai bukti diri, akibatnya mereka ini tidak bisa melakukan perbuatan hukum. Untuk mengatasi itu maka dibuatlah perjanjian-perjanjian Internasional di antaranya, Perjanjian Internasional 1928，1933，1938， 1939 dan 1946. Perjanjian-perjanjian ini diteruskan oleh PBB dengan diadakan Konferensi mengenai status pengungsi tahun 1951, yang dilengkapi dengan Protokol di tahun 1967. Pasca bubarnya LBB dan dibentuknya PBB, PBB membentuk International Refugee Organization (IRO) dengan mandat melindungi kelompok-kelompok pengungsi yang telah diakui LBB. IRO kemudian digantikan oleh United Nations High Commissioner for Refugees (UNHCR) (M. Husni Syam;2009). Langkah awal yang dilakukan UNHCR adalah mengadakan konvensi, yaitu Konvensi di tahun 1951. Konvensi 1951 merupakan titik awal dari setiap pembahasan mengenai persoalan pengungsi. Sehubungan persoalan pengungsi semakin meningkat pada akhir tahun 1950 dan awal tahun 1960an, maka dipandang perlu untuk memperluas cakupan waktu dan geografis dari Konvensi 1951. Oleh karena itu dalam perkembangannya dirancang dan disepakati suatu protokol tambahan terhadap konvensi tentang status 
pengungsi tersebut, yakni Protokol 1967 (Sigit;2004).

Indonesia merupakan salah satu negara yang harus berhadapan dengan permasalahan orang asing pencari suaka dan pengungsi yang masuk dan tinggal di wilayah Indonesia. Untuk pertama kalinya, pada tahun 1979 Indonesia berurusan dengan masalah yang menyangkut pada pengungsi dan pencari suaka dalam jumlah besar. Pada saat itu, pengungsi dan pencari suaka dari Vietnam tiba di Indonesia sebagai akibat dari Indo-China perang antara Republik Rakyat Cina dan Vietnam. Sekitar 170.000 pengungsi dan pencari suaka datang ke Indonesia untuk mencari perlindungan (UNHCR). Mereka mencari perlindungan tersebut melalui jalur darat dan ada melalui jalur laut sehingga mereka dikenal dengan manusia perahu (boat people). Indonesia belum menjadi pihak pada Konvensi Tahun 1951 dan Protokol 1967. Dari hal tersebut Indonesia tidak mempunyai wewenang dalam memberikan RSD atau status pengungsi. Sehingga pengaturan permasalahan mengenai pengungsi ditetapkan oleh UNHCR (Komisi Tinggi PBB bidang Pengungsi) sesuai dengan mandat yang diterimanya berdasarkan statuta UNHCR Tahun 1950. Semua negara termasuk yang belum meratifikasi konvensi pengungsi wajib menjunjung tinggi standar perlindungan pengungsi yang telah menjadi bagian dari hukum internasional umum, karena konvensi tersebut sudah menjadi jus cogens dan tidak seorang pengungsipun dapat dikembalikan ke wilayah di mana hidup atau kebebasannya terancam (Atik Krustiyati;2012). Dengan Indonesia belum meratifikasi perjanjian internasional mengenai pengungsi dan pencari suaka yaitu Konvensi Internasional 1951 dan Protokol 1967, berbagai persoalan muncul ketika pemerintah tidak tanggap dalam menangani para pengungsi ataupun pencari suaka itu. Pemerintah Indonesia tidak dapat menentukan sendiri status mereka karena Pemerintah Indonesia bukanlah negara pihak yang menandatangani dan meratifikasi Konvensi 1951 ataupun Protokol 1967 tentang status pengungsi.

\section{Perumusan Masalah}

1. Mengapa Indonesia belum meratifikasi Konvensi 1951 dan Protokol 1967?

2. Bagaimana akibat hukumnya apabila Indonesia meratifikasi Konvensi 1951 dan Protokol 1967?

\section{Tujuan Penulisan}

Sehubungan dengan kedua pokok permasalahan di atas, maka penelitian ini bertujuan:

1. Untuk mengetahui alasan Indonesia belum meratifikasi Konvensi 1951 dan Protokol 1967

2. Untuk mengetahui bagaimana akibat hukumnya apabila Indonesia meratifikasi Konvensi 1951 dan Protokol 1967

\section{Manfaat}

Adapun manfaat dari penelitian ini adalah sebagai berikut:

1. Diharapkan, penelitian ini dapat memberikan kontribusi secara teoritis bagi penggiat hukum internasional yang khususnya mengenai kemampuan suatu negara dalam menjalin kerjasama melalui perjanjian internasional

2. Hasil dari penelitian ini diharapkan pula dapat memberikan informasi kepada masyarakat umum dan juga pemerintah dalam menanggapi kasus yang serupa jika terjadi di masa yang akan datang. 


\section{Metode Penelitian}

Jenis penelitian dalam artikel ini adalah penelitian yuridis normative yakni penelitian hukum yang menggunakan sumber data sekunder atau data yang diperoleh melalui bahan-bahan kepustakaan. Obyek penelitian pada penelitian ini adalah Konvensi 1951 dan Protokol 1967 itu sendiri dari persepktif hukum internasional. Sumber data yang digunakan dalam penelitian ini adalah data sekunder yang terdiri dari bahan hukum primer, bahan hukum sekunder, dan bahan hukum tersier. Pada penelitian ini, penulis menggunakan teknik pengumpulan data melalui studi kepustakaan. Hal yang dilakukan oleh peneliti adalah membahas dan menganalisis terkait alasan Indonesia belum meratifikasi Konvensi 1951 dan Protokol 1967 akibat hukumnya apabila Indonesia meratifikasi Konvensi 1951 dan Protokol 1967 untuk menjawab rumusan masalah pertama dan kedua. Penelitian ini dilakukan dengan cara mengumpulkan dan mempelajari bahan hukum primer, sekunder, dan tertier. Bahan hukum primer seperti Konvensi 1951, Protokol 1967 dan lain-lain. Bahan hukum sekunder seperti buku-buku, artikel, pendapat pakar hukum internasional maupun jurnal dan makalah yang berhubungan dengan topik penulisan ini. Bahan hukum tertier adalah bahan hukum penunjang yang memberikan petunjuk terhadap bahan hukum primer dan sekunder seperti kamus hukum, kamus bahasa, dan lainlain. Untuk menganalisis data dan menarik kesimpulan dari penelitian ini, penulis melakukan analisis dengan metode kualitatif untuk selanjutnya disajikan dalam bentuk preskriptis analisis yang menggunakan metode pendekatan historis yaitu dengan membahas latar belakang lahirnya dan perkembangan pengaturan mengenai masalah yang diteliti, sekaligus dikaitkan dengan peraturan-peraturan hukum yang ada, serta pendekatan "statute approach", yaitu dengan pendekatan melalui peraturan perundang-undangan serta perjanjian internasional dan dan pendekatan hukum secara empiris/sosiologis.

\section{Pembahasan}

\section{Konvensi 1951 Dan Protokol 1967}

Konvensi 1951 dan Protokol 1967 menyusun standar minimum bagi perlakuan terhadap pengungsi, termasuk hak dasar mereka. Konvensi juga menetapkan status hukum dari pengungsi tersebut dan mencantumkan ketentuanketentuan tentang hak-hak mereka. Adapun diantaranya yaitu:

1. Untuk mendapatkan pekerjaan dan kesejahteraan,

2. Mendapatkan surat keterangan jati diri dan dokumen perjalanan serta mengenai penerapan biaya fiskal,

3. Hak untuk memindahkan aset miliknya ke negara lain dimana mereka telah diterima dengan tujuan permukiman kembali.

Konvensi melarang pengusiran dan pemulangan paksa terhadap orangorang berstatus pengungsi. Hal ini tercantum dalam Pasal 33 Konvensi 1951. Dalam pasal 33 Konvensi menetapkan bahwa tidak satupun negara pihak dapat mengusir atau mengembalikan (memulangkan kembali) pengungsi dengan alasan apapun ke wilayah perbatasan dimana jiwa atau kemerdekaan mereka akan terancam karena pertimbangan ras, agama, kewarganegaraan, anggota dari kelompok sosial atau pendapat politik tertentu. Dalam Pasal 34 Konvensi 1951 membahas persoalan naturalisasi dan asimilasi bagi pengungsi.

Dalam Pasal 34 ini adanya ketentuanketentuan lain berkenaan dengan masalah hak atas akses terhadap pengadilan, pendidikan, jaminan sosial, 
perumahan dan kebebasan untuk bergerak. Ketetapan-ketetapan utama konvensi 1951 dapat dikelompokan menjadi dua bagian yaitu

1. Ketetapan-ketetapan yang memuat definisi dasar mengenai siapa itu pengungsi, siapa saja yang sudah tidak menjadi pengungsi lagi dan siapa saja yang pengungsi dari status pengungsi.

2. Ketetapan-ketetapan yang mendefenisikan status bukan pengungsi, hak dan kewajiban mereka (www.unlicr.orv).

Aturan-aturan dalam Konvensi 1951 dan Protokol 1967, yaitu:

\section{Defend pengungsi}

Tujuan pokok konvensi ini adalah menyediakan aturan hukum yang menjamin perlindungan terhadap sekelompok orang yang berada dalam keadaan yang sangat rawan. Pasal 1 konvensi mendefenisiskan pengungsi sebagai seseorang, yang karena rasa takut yang beralasan akan adanya persekusi oleh karena alasan-alasan ras, agama, kebangsaan, keanggotaan pada suatu kelompok sosial atau pandangan politik tertentu, berada diluar negara dimana ia menjadi warganegara dan tidak bisa mendapatkan atau tidak mau mendapatkan kesempatan perlindungan negara tersebut karena alasan rasa takut tadi; atau sesesorang yang, karena tidak mempunyai kewarganegaraan dan berada diluar negara yang biasa la tinggali sebelum kejadian tersebut, tidak atau tidau mau kembali ke negara tersebut karena rasa takut.

Jadi seorang pengungsi adalah seseorang yang berada diluar negara asalnya atau ternpat tinggal yang biasa dan karena rasa takut yang beralasan akan adanya persekusi yang disebabkan oleh karena alasan-alasan ras, agama, kebangsaan, keanggotaan pada kelompok sosial atau pandangan politik tertentu, maka tidak bisa atau tidak mau mendapatkan perlindungan dari negara tersebut yang dalam keadaan normal merupakan haknya (www.unhcr.org). Keputusan atas apakah seorang berhak atas status pengungsi diambil oleh tiap negara bersangkutan sesuai dengan prosedur yang ditetapkannya sendiri, dari konsisten dengan standar internasional, dengan dasar kriteria yang terdapat dalam pasal 1 konvensi UNHCR memainkan peranan dalam prosedur ini bila sebagaimana diminta oleh negaranegara bersangkutan, dengan demikian bisa menyumbangkan pengalamannya yang bertahun-tahun kepada pemerintah bersangkutan mengenai penentuan status pengungsi dan penanganan umum masalah pengungsi.

2. Penghentian Status Pengungsi

Dalam Pasal 1 C Konvensi 1951 tersebut memberikan persyaratan kepada seseorang untuk dihentikan statusnya sebagai pengungsi apabila:

a. Telah dengan sukarela mendapatkan kembali kesempatan perlindungan dari negara dimana dia menjadi warganegara.

b. Setelah kehilangan kewarganegaraannya, dengan sukarela mendapatkannya.

c. Mendapatkan kewarganegeraan baru dan menikmati perlindungan dari negara dimana la menjadi warganegara baru.

d. Dengan sukarela telah bermukim kembali di negara yang sebelumnya telah ditinggalkannya atau ia dengan sukarela bermukim kembali di luar negara yang la tinggalkan karena alasan persekusi.

e. Keadaan yang berhubungan dengan diakuinya sebagai pengungsi telah tidak ada lagi, dan dia tidak bisa menolak lagi perlindungan bagi negara dimana ia menjadi warganegara, atau,

f. Tidak berkewarganegaraan, tetapi oleh karena keadaan yang membuat 
diakui sebagai pengungsi telah tidak ada lagi, membuatnya bisa kembali ke negara yang sebelumnya menjadi tempat tinggalnya (www.unhcr.org).

3. Pengecualian dari Status Pengungsi

Dalam Konvensi 1951 juga dibahas mengenal kasus-kasus tentang orang orang yang meskipun mempunyai ciri-ciri pengungsi, dikecualikan dan status pengungsi. Orang-orang tersebut dikelompokkan menjadi tiga bagian. Kelompok ini terdiri dari orang-orang yang telah menerima perlindungan atau bantuan dari badan-badan atau organ Perserikatan Bangsa-Bangsa selain UNHCR. Misalnya kaum Palestina yang dibeberapa bagian Timur Tengah menerima bantuan dari United Nations Releif and Works Agency atau UNRWA bagi pengungsi Palestina.

4. Terdiri dari orang-orang yang tidak dianggap memerlukan perlindungan internasional. Ketetapan ini mengacu pada orang-orang yang telah diterima oleh suatu negara dimana mereka telah diberi sebagian besar hak yang normalnya hanya dinikmati oleh warganegara yang bersangkutan, dalam hal ini dengan pengecualian kewarganegaraan resmi. Orang-orang keturunan Jerman dari Eropa Tengah dan bekas Uni Soviet tanpa memandang kewarganegaraan mereka, semua dilindungi oleh konstitusi Jerman, dan oleh sebab itu mereka bukan pengungsi menurut Konvensi 1951.

5. Kelompok yang terdiri dari kategori orang-orang yang telah dianggap berhak mendapatkan perlindungan internasional, karena mereka telah melakukan tindakan kejahatan namun terhadap perdamaian, kejahatan perang atau kejahatan terhadap kemanusiaan, atau kejahatan non politik yang serius di luar negara tempat mengungsi sebelum mereka diterima masuk di negara tersebut sebagai pengungsi, atau mereka telah bersalah karena melakukan tindakan-tindakan yang bertentangan dengan tujuan dan prinsip-prinsip Perserikatan BangsaBangsa.

6. Hak-Hak Pengungsi

Untuk menjamin status hukum pengungsi di negara pemberi suaka, konvensi mengandung ketetapanketetapan komprehensif mengenai hak-hak pengungsi. Kecuali bila hak-hak yang lebih menguntungkan dinyatakan secara jelas dalam konvensi, para pengungsi diberi standar minimum hak yang sama sebagaimana diberikan kepada orang asing pada umumnya. Seorang pengungsi juga diberi hakhak khusus yang normalnya tidak dinikmati oleh orang asing karena adanya kenyataan bahwa dia tidak mendapat perlindungan dari negara dimana dia adalah warganegaranya (www.unhcr.org). Hak-hak pengungsi adalah sebagal berikut:

a. Hak untuk tidak dipulangkan ke suatu negara dimana mereka mempunyai alasan untuk takut terhadap suatu persekusi.

b. Hak untuk tidak diusir, kecuali dalam keadaan-keadaan tertentu, seperti keamanan nasional dan ketertiban umum.

c. Pengecualian dari hukuman karena masuk secara tidak sah ke wilayah negara yang menjadi pihak pada Konvensi karena keadaan dimana para pengungsi terpaksa meninggalkan tanah air mereka, maka boleh jadi tidak mungkin bagi mereka untuk masuk ke negara yang berpontensi memberi suaka kepada mereka dengan cara yang biasa, misalnya dengan paspor atau visa masuk yang 
sah. Biasanya, masuk atau keberadaan secara tidak sah seperti itu, bagaimanapun juga, tidak boleh diiatuhkan terhadap pengungsi.

d. Hak bergerak dengan bebas, negara-negara peserta secara hukurn wajib mernberikan kepada pengungsi di wilayah mereka hak untuk memilih tempat tinggal dan bergerak secara bebas didalarn wilayah mereka, sesual dengan peraturan yang berlaku bagi orang asing pada umumnya pada kondisi yang sama.

e. Kebebasan beragama dan akses yang bebas ke pengadilan.

f. Identitas dan dokumen perjalanan.

g. Hak untuk mendapatkan pekerjaan dan perumahan.

h. Akses untuk mendapatkan pendidikan formal.

i. Bantuan pemerintah dan peraturan perburuhan serta jarninan sosial

7. Kewajiban Para Pengungsi

Para pengungsi adalah orang-orang asing yang berada dalam keadaan yang sangat rawan. Hal ini tidak membuat mereka lepas dari kewajiban mereka sebagai orang yang tinggal di negara lain. Para pengungsi inernpunyal kewajiban kepada negara tempat mereka mendapat suaka, dan harus, mematuhi undanganundangan dan peraturan yang ada, dan juga berwenang tindakantindakan yang diambil oleh yang berwenang demi pemeliharaan ketertiban umum (www.unhcr.org).

\section{Belum diratifikasinya Konvensi 1951 Tentang Penentuan Status Pengungsi Dan Protokol 1967}

Penanganan pengungsi di Indonesia mengalami kesulitan karena sampai saat ini Indonesia belum menjadi pihak pada
Konvensi Jenewa Tahun 1951 tentang Pengungsi dan Protokol 1967. Negara pihak peserta Konvensi 1951 memiliki tanggung jawab dan wewenang dalam menentukan status serta kelangsungan hidup pengungsi beserta semua implikasinya. Dengan demikian, maka bukan lagi wewenang UNHCR dalam mengurus masalah pengungsi. Posisi Indonesia sebagai negara bukan peratifkasi konvensi 1951 menyebabkan Indonesia tidak memiliki kewajiban dalam menangani masalah pengungsi. Dalam kondisi yang demikian, Indonesia belum mengeluarkan ketentuan yang memiliki kekuatan yuridis bagi pengungsi dan pencari suaka dan pemerintah Indonesia tidak memiliki keterlibatan yang lebih daripada sebagai negara persinggahan sementara setra membantu mecarikan tempat bagi pengungsi sampai mereka diberangkatkan ke negara tujuan yang ditawarkan atau direpatriasi.

Dengan belum menjadi pihak pada Konvensi Tahun 1951 dan Protokol 1967, maka Pemerintah Indonesia juga tidak mempunyai kewenangan untuk memberikan penentuan status pengungsi atau yang biasa disebut dengan "Refugee Status Determination"(RSD), sehingga pengaturan permasalahan mengenai pengungsi ditetapkan oleh UNHCR (Badan PBB yang mengurusi soal pengungsi) sesuai dengan mandat yang diterimanya berdasarkan Statuta UNHCR Tahun 1950. Kewenangan tersebut dilakukan mengingat bahwa Indonesia bukan negara pihak Konvensi Tahun 1951. Semua negara termasuk yang belum meratifikasi Konvensi Pengungsi wajib menjunjung tinggi standar perlindungan pengungsi yang telah menjadi bagian dari hukum Internasional umum, karena konvensi tersebut sudah menjadi jus cogens, dan tak seorang pengungsi pun dapat dikembalikan ke wilayah di mana hidup 
atau kebebasannya terancam (Atik Krustiyati). Indonesia tidak mempunyai payung hukum untuk penanganan pengungsi di Indonesia., padahal dari hari kehari jumlah pengungsi yang masuk ke Indonesia semakin banyak. Ketiadaan peraturan hukum khusus mengenai pengungsi menyebabkan kekosongan hukum dalam menangani pengungsi. Pada level praktis ketiadaan instrument hukum ini telah menimbulkan kebingungan dan tumpang-tindih kewenangan di antara institusi-institusi yang merasa berkepentingan untuk menangani persoalan-persoalan yang berkaitan dengan pengungsi dan pencari suaka di Indonesia. Dengan adanya kekosongan instrument hukum operasional untuk menjadi rujukan bagi institusi yang berkepentingan untuk mengantisipasi persoalan pengungsi dan pencari suaka ini jelaslah bahwa instrument hukum pengungsi perlu dilembagakan dalam sistem hukum nasional di Indonesia (Atik Krustiyati;2009).

\section{Alasan Pemerintah Indonesia Menunda Ratifikasi Konvensi 1951 dan Protokol 1967 Tentang Status Pengungsi}

Di sebagian besar negara, persetujuan formal oleh badan legislatif nasional diperlukan untuk meratifikasi atau menyetujui sebuah perjanjian. Ratifikasi sebuah Konvensi biasanya memerlukan beberapa langkah yang dilakukan oleh badan eksekutif dan badan legislatif pemerintahan. Begitu badan eksekutif telah menyetujui ratifikasi atau persetujuan terhadap Konvensi tersebut, maka biasanya akan menyusun dan menyampaikan proposal ratifikasi kepada badan legislative nasional.Lembaga legislatif merupakan badan perwakilan rakyat yang memiliki otoritas untuk membuat sebuah kebijakan untuk rakyat disuatu negara.
Indonesia memiliki peraturan yang mengatur kinerja dari lembaga legislatif (DPR-RI), hal ini tertuang didalam UU No. 37 Tahun 1999, pasal 6 (Syahmin;2008). Dalam pasal tersebut menjelaskan bahwa untuk mengesahkan sebuah perjanjian Internasional dengan negara lain, wewenang tersebut diberikan kepada DPR untuk mengesahkan sebuah perjanjian Internasional sebelum disahkan oleh presiden sendiri. Pada dasarnya lembaga legislatif Indonesia dalam hal ini DPR, mendukung ratifikasi Konvensi 1951 dan Protokol 1967 tersebut. Tetapi, proses ratifikasi suatu perjanjian Internasional baik bilateral maupun multilateral menempatkan DPR pada pihak yang pasif, dalam arti menunggu adanya pengajuan dari pemerintah. Akibatnya lembaga legislatif tidak dapat membuat rancangan undang-undang tersebut. Lembaga eksekutif dalam hal ini pemerintah belum mengajukan permintaan untuk meratifikasi Konvensi 1951 dan Protokol 1967, hal ini bukan dikarenakan sikap tidak setuju pemerintah terhadap ratifikasi hukum pengungsi Internasional tersebut.

Rencana atau program ratifikasi Konvensi 1951 dan Protokol 1967 tentang Status Pengungsi telah dicantumkan dalam dua periode Rencana Aksi Nasional Hak Asasi Manusia (RANHAM), yaitu periode tahun 2004-2009 dan periode tahun2010-2014. Pada periode RANHAM tahun 2004-2009, ratifikasi kedua hukum pengungsi Internasional tersebut direncanakan akan direalisasikan pada tahun 2009. Namun rencana ratifikasi tersebut tertunda sampai dibuatnya RANHAM periode tahun 2010-2014. Direncanakan kembali Konvensi 1951 akan diratifikasi pada tahun 2013 sementara Protokol 1967 pada tahun 2014 yang sampai saat ini belum terlaksana setelah kepemimpinan 
Presiden Susilo Bambang Yudhoyono digantikan oleh Pesiden Joko Widodo. Melalui RANHAM periode 2004-2009 dan 2010-2014 pemerintah telah menunjukkan respon yang positif terhadap usaha ratifikasi Konvensi 1951 dan Protokol 1967. Namun, karena kondisi negara saat ini yang rentan sehingga tidak memungkinkan untuk meratifikasi Konvensi dan Protokol tersebut. Untuk itu pemerintah menunda ratifikasi Konvensi 1951 dan Protokol 1967 dengan memperhatikan beberapa faktor-faktor pendukung dan penghambat yangmenjadi pertimbangan pemerintah Indonesia. Faktor-faktor tersebut diantaranya:

\section{Faktor Pendukung Pemerintah Indonesia untuk Meratifikasi Konvensi 1951 dan Protokol 1967}

Ketiadaan Hukum Nasional terkait Penanganan Pengungsi di Indonesia. UU No. 37 Tahun 1999 Tentang Hubungan Luar Negeri pada Bab VI Pasal 25-27 yang selama ini digunakan sebagai acuan dalam pemberian suaka dan penanganan pengungsi, sama sekali tidak menjelaskan secara khusus bagaimana proses pemberian suaka maupun penanganan pengungsi yang harus dilakukan oleh pemerintah Indonesia. Peraturan dan UU yang dibuat oleh pemerintah tersebut, pada dasarnya sudah tidak dapat lagi menjawab permasalahan pengungsi di Indonesia. Ketiadaan hukum nasional mengenai penanganan pengungsi tersebut, membuat ketidakjelasan tugas lembaga dan instansi yang terkait dalam penanganan pengungsi yang menyebabkan adanya kebijakan yang tumpang-tindih antar lembaga. Dari segi keimigrasian sendiri, berdasarkan UU, pengungsi masih dikategorikan sebagai imigran ilegal. Sehingga petugas imigrasi masih memperlakukan pengungsi sebagai kriminal seperti imigran ilegal lainnya. Sementara disisi lain, dari segi kemanusiaan, pengungsi tidak dapat disamakan dengan imigran ilegal. Pengungsi berdasarkan Konvensi 1951 dan Protokol 1967 memiliki hak sama seperti warga negara lain di negara mereka berada. Perbedaan persepsi ini secara tidak langsung semakin melemahkan penegakan dan pengawasan hukum di Indonesia.

\section{Faktor Penghambat Pemerintah Indonesia untuk Meratifikasi Konvensi 1951 dan Protokol 1967 Faktor Eksternal}

Beberapa Pasal dalam Konvensi 1951 dan Protokol 1967 yang Sulit Dipenuhi oleh Pemerintah Indonesia.

Konvensi dan Protokol 1967 telah menetapkan aturan dan norma yang harus dipenuhi oleh negara-negara peratifikasi melalui pasal-pasal yang terdapat didalamnya. Diantara pasalpasal tersebut, ada beberapa pasal dalam Konvensi 1951 yang cukup berat dan sulit dipenuhi oleh pemerintah Indonesia. Pasal-pasal tersebut diantaranya adalah Pasal 13, 14, dan 30, yaitu negara peratifikasi diwajibkan membantu atau bahkan mempermudah pemindahan hak milik dan asetaset pengungsi ke negara tempat ia akan menetap Pasal 17, 18 dan 19. Ketiga pasal ini pada dasarnya memberikan kebebebasan kepada pengungsi untuk mendapatkan pekerjaan yang menghasilkan upah, melakukan usaha sendiri seperti pertanian dan mendirikan perusahaan. Di sisi lain, pemerintah masih kesulitan dalam menciptakan lapangan pekerjaan bagi warga negaranya, yang berakibat pada banyaknya jumlah pengangguran di Indonesia akibat sulitnya masyarakat Indonesia untuk mendapatkan pekerjaan. Pasal 22. Pengungsi mempunyai hak untuk mendapatkan pendidikan dan pemerintah berkewajiban untuk 
memenuhinya. Pemerintah tentunya mengalami dilema tersendiri dalam hal ini. Disatu sisi, masih banyak masyarakat Indonesia yang belum mendapatkan pendidikan. Sementara disisi yang lain, pemerintah diwajibkan memberikan pendidikan kepada para pengungsi Pasal 21 dan 24. Kedua pasal ini pada intinya memberikan hak atas kesejahteraan kepada pengungsi seperti perumahan dan tunjangan-tunjangan. Pasal ini secara tidak langsung mengharuskan negara peratifikasi untuk menyiapkan anggaran lebih guna memenuhi tunjangan-tunjangan selain upah yang diterima dalam pekerjaannya.

\section{Berkurangnya Keterlibatan UNHCR Dalam Penanganan Pengungsi di Indonesia.}

Seperti yang diketahui, UNHCR banyak terlibat dalam penanganan pengungsi di Indonesia. Bahkan sebagai negara yang belum meratifikasi Konvensi 1951 dan Protokol 1967, UNHCR adalah lembaga yang diberikan hak untuk menentukan status pengungsi di Indonesia. Dengan anggaran terbatas untuk penanganan pengungsi dan pencari suaka yang dimiliki Indonesia, kehadiran UNHCR tentu sangat membantu Indonesia mengatasi persoalan tersebut. Ketika Indonesia memutuskan untuk meratifikasi Konvensi 1951 dan Protokol 1967, maka keterlibatan UNHCR dalam proses penanganan pengungsi di Indonesia akan sangat berkurang. Mandat proses penentuan status pengungsi yang dimiliki oleh UNHCR dan pemenuhan kebutuhan pengungsi dan pencari suaka selama berada di Indonesia akan langsung dilimpahkan kepada pemerintah Indonesia. Untuk kebutuhan pengungsi dan pencari suaka sendiri, pemerintah perlu membuat anggaran khusus untuk memenuhi hakhak mereka sesuai dengan Konvensi 1951 dan Protokol 1967.
Kekhawatiran Meningkatnya Jumlah Pengungsi dan Kejahatan Lintas Batas Negara (Transnasional)

Jika kedua rezim pengungsi tersebut diratifikasi, pemerintah berkewajiban melindungi pengungsi selama berada di wilayah Indonesia. Pemerintah tidak dapat lagi memperlakukan pengungsi seperti imigran ilegal dan menampung mereka di rudenim. Dengan begitu, pengungsi akan merasa sangat aman jika memasuki wilayah Indonesia, karena perlindungan dan hak-hak yang dapat mereka terima dari pemerintah Indonesia. Sehingga secara tidak langsung, jumlah pengungsi di Indonesia juga dapat semakin meningkat.Belum lagi negara tujuan pengungsi, Australia, semakin meningkatkan aturan hukum nasionalnya tentang penanganan pengungsi. Sehingga tidak menutup kemungkinan status Indonesia dari yang awalnya hanya sebagai negara transit akan meningkat menjadi negara tujuan bagi para pengungsi. Masuknya individu yang menyatakan diri sebagai pengungsi namun tidak memiliki dokumen yang resmi, membuat pemerintah tidak dapat mengetahui identitas para pengungsi secara detail, yang kemudian menyebabkan lemahnya pengawasan terhadap para pengungsi. Hal ini tentunya menjadi potensi ancaman tersendiri bagi Indonesia. Beberapa individu yang mengaku pengungsi, bisa saja memiliki maksud dan tujuan tertentu memasuki wilayah Indonesia, yang secara tidak langsung dapat menyebabkan potensi bahaya bagi Indonesia, terutama bagi warga negara Indonesia.

\section{Faktor Internal}

Penguatan Kapasitas Hukum di Indonesia.

Jika pemerintah memutuskan untuk meratifikasi Konvensi 1951 dan Protokol 1967, maka pemerintah harus 
meningkatkan kekuatan hukum di Indonesia. Salah satunya adalah dengan meningkatkan pengawasan diperbatasan serta pertahanan dan keamanan maritim. Pertahanan dan keamanan maritim tentunya membutuhkan pengadaan peralatan dan persenjataan yang lengkap dan dalam kondisi yang baik, bagi petugas dalam berpatroli di laut dan wilayah perbatasan Indonesia. Sementara itu peningkatan pengawasan perbatasan serta pertahanan dan keamanan maritim sendiri, tidak hanya dilihat melalui sisi militer atau pengadaan peralatan dan persenjataan yang lengkap semata.

Meningkatnya Jumlah Biaya yang Harus Dikeluarkan Oleh Pemerintah Untuk Menangani Pengungsi.

Ratifikasi Konvensi 1951 dan Protokol 1967 tentunya juga dapat berdampak pada perekonomian Indonesia. Hal ini terkait dengan pembiayaan penanganan pengungsi dan pencari suaka akan sepenuhnya ditanggung oleh Pemerintah. Biaya tersebut antara lain untuk:

1) Membiayai pelatihan bagi instansi yang nantinya akan terkait baik secara langsung maupun tidak langsung terhadap penanganan pengungsi. Seperti Kepolisian, Angkatan Laut, petugas di TPI, Dirjen Imigrasi, Kementerian Hukum dan Hak Asasi Manusia, termasuk Kementerian Luar Negeri.

2) Menentukan status pengungsi juga memerlukan dana yang tidak sedikit. Dana ini diantaranya adalah pembiayaan tenaga-tenaga professional dalam registrasi dan wawancara terhadap pengungsi dan atau pencari suaka. Karena tidak semua pengungsi dapat berkomunikasi menggunakan bahasa inggris terlebih lagi bahasa Indonesia, maka dibutuhkan interpreter terpercaya berdasarkan kebutuhan pada saat registrasi sesuai dengan bahasa yang dapat dimengerti oleh interpreter dan pengungsi atau pencari suaka. Selain itu selama proses penentuan status pengungsi, Indonesia juga berkewajiban memberikan dan memenuhi kebutuhan dasar pengungsi seperti tempat tinggal, makanan, pendidikan dan lain sebagainya.

Setelah status pengungsi ditetapkan, maka selanjutnya menentukan solusi jangka panjang bagi para pengungsi. Jika integrasi lokal tidak dapat dipenuhi oleh pemerintah, maka pengungsi akan diberikan pilihan berupa pemulangan sukarela ke negara asal (repatriasi sukarela) dengan syarat kondisi negara asal telah kondusif atau pilihan resettlement untuk ditempatkan ke negaranegaraketiga. Biaya untuk kedua pilihan tersebut tentunya tidak sedikit terlebih lagi dengan jumlah pengungsi yang sangat banyak. Selain itu proses masuknya pengungsi yang tidak melengkapi dokumen imigrasi tentunya tidak melakukan prosedur migrasi dengan benar dapat membuat suatu negara mengalami kerugian karena tidak terkena devisa. Dimana devisa merupakan salah satu penghasilan negara, sehingga negara tersebut akan mengalami kerugian. Dari segi ekonomi, maka tentunya pemerintah tidak hanya mengalami kerugian akibat devisa yang tidak didapat oleh masuknya pengungsi, tetapi juga pemerintah harus memiliki anggaran khusus untuk menangani pengungsi.

a. Kondisi Sosial Budaya Masyarakat Indonesia.

Jika pemerintah meratifikasi Konvensi dan Protokol tersebut, maka 
ada beberapa solusi jangka panjang untuk penanganan pengungsi yang harus dilakukan oleh pemerintah Indonesia, yang ada terdiri dari integrasi lokal, pemulangan secara sukarela, atau penempatan di negara ketiga. Ketika terjadi integrasi lokal, jika pengungsi dan masyarakat tidak dapat hidup berdampingan sebagaimana harapan pemerintah, tentunya dapat menimbulkan konflik internal dan masalah baru yang dapat mengganggu ketertiban dan keamanan sosial di Indonesia. Perlakuan yang didapat pengungsi dari pemerintah jika meratifikasi rezim pengungsi Internasional tersebut dapat menimbulkan persepsi negatif di masyarakat. Hal yang dapat memicu munculnya persepsi negatif dan permasalahan baru tersebut yaitu kecemburuan sosial antara masyarakat setempat dan pengungsi. Masyarakat Indonesia yang belum dapat merasakan perlakuan yang sama seperti yang didapatkan pengungsi, tentunya akan merasa kurang atau bahkan tidak mendapat perhatian dari pemerintah dibandingkan dengan pengungsi yang sudah jelas hanya pendatang. Keberadaan pengungsi di Indonesia yang terdiri dari berbagai macam budaya tentunya juga dapat berpengaruh. Ini terutama terjadi karena para pengungsi tetap memilih untuk mempertahankan identitas budaya yang tidak selalu selaras dengan nilai-nilai masyarakat setempat. Masuknya budaya asing yang tidak sesuai dengan kepribadian bangsa, secara tidak langsung dapat mempengaruhi bahkan merubah budaya bangsa masyarakat Indonesia.

\section{Perlunya Indonesia Meratifikasi Konvensi 1951 dan Protokol 1967}

Keberadaan pengungsi yang jumlahnya cenderung meningkat yang membuat usaha penanganan pengungsi terus diperhatikan oleh pemerintah Indonesia. Disisi lain, Indonesia tidak memiliki undang-undang khusus atau peraturan hukum nasional mengenai pengungsi maupun pencari suaka. Indonesia memang memiliki acuan dalam pemberian suaka dan penanganan pengungsi seperti yang tertuang dalam UU No. 37 Tahun 1999 tentang Hubungan Internasional. Akan tetapi pada pelaksanaanya peraturan tersebut kurang efektif dikarenakan sudah tidak up to date untuk menangani permasalahan pengungsi saat ini, dikarenakan undang-undang tersebut tidak menjelaskan secara eksplisit bagaimana penanganan pengungsi yang harus dilakukan. Dengan belum diratifikasinya Konvensi 1951 dan Protokol 1967 maka pemerintah Indonesia tidak punya wewenang dalam menangani masalah pengungsi yang berada di wilayah Negara Kesatuan Republik Indonesia. Sehingga wewenang penuh dalam menangani pengungsi diberikan kepada UNHCR. Sebelum menjadi pihak pada Konvensi 1951 dan atau Protokol 1967, ada baiknya melihat hak apa saja yang dipunyai oleh pengungsi, agar dapat dipertimbangkan apakah suatu negara khususnya Pemerintah Indonesia mampu memenuhi hak tersebut ataukah tidak. Beberapa hak tersebut antara lain:

a. Kebebasan mempraktekkan agama dan pendidikan agama bagi anakanak pengungsi (Pasal 4);

b. Hak atas milik bergerak dan tidak bergerak (Pasal 13);

c. Hak berserikat (Pasal 15); 4. Hak berswakarya (Pasal 18);

d. Hak menjalankan profesi liberal (Pasal 19);

e. Hak atas pendidikan (Pasal 22);

f. Hak atas kondisi kerja yang layak dan jaminan sosial (Pasal 24);

g. Kebebasan berpindah tempat (Pasal 26). 
Mencermati beberapa hak tersebut di atas, maka yang tidak boleh direservasi adalah ketentuan Pasal 4. Pasal-pasal lain yang tidak boleh dilakukan reservasi, dapat dilihat dalam ketentuan pasal 42 Konvensi 1951, yaitu:

a. Definisi istilah pengungsi (pasal 1);

b. Non diskriminasi (pasal 3);

c. Kebebasan beragama (pasal 4 );

d. Akses ke pengadilan (pasal 6 ayat 1 );

e. Non Refoulement (pasal 33)

f. Klausula akhir (pasal 36-46).

1. Landasan Teori dan Konseptual

Terdapat landasan teori dan konseptual yang melatarbelakangi perlunya Indonesia meratfikasi Konvensi 1951 dan Protokol 1967 antara lain:

\section{a. Konsep Kepentingan Nasional (National Interest)}

Kepentingan Nasional (National Interest) adalah tujuan-tujuan yang ingin dicapai sehubungan dengan kebutuhan bangsa/negara atau sehubungan dengan hal yang dicitacitakan. Dalam hal ini kepentingan nasional yang relatif tetap dan sama diantara semua negara adalah keamanan (security) mencakup kelangsungan hidup rakyatnya dan kebutuhan wilayah serta kesejahteraan (prosperity). Kepentingan nasional sering dijadikan tolak ukur atau kriteria pokok bagi para pengambil keputusan (decision makers) masing-masing negara sebelum merumuskan dan menetapkan sikap atau tindakan (Ria Rosiana Simbolon;2004). Konsep kepentingan nasional mengarah kepada tujuan kesejahteraan negara di dunia Internasional, seperti memelihara dan menjaga interdependensi politik serta integritas teritori negara. Selain itu, kepentingan nasional sejatinya berbanding lurus dengan keamanan nasional (Felix E Oppenheim;1987). Donald E. Nuchterlein menyatakan bahwa kepentingan nasional adalah kebutuhan dan tujuan yang ingin dicapai suatu negara yang juga dipengaruhi oleh faktor lingkungan eksternal (Donal E. Nuchterlein;1979). Dalam hal ratifikasi Konvensi 1951 dan Protokol 1967, pemerintah merasa perlu memperhatikan dan mempertimbangkan kondisi dan resiko pasca ratifikasi, yang sangat mempengaruhi kepentingan dasar negara berupa physical safety dan material wellbeing agar dapat mencapai kepentingan nasional tingkat core values.

b. Teori Rezim Internasional (International Regime Theory)

Teori rezim berasal dari tradisi liberal yang berargumen bahwa berbagai institusi atau rezim Internasional mempengaruhi perilaku negara-negara (maupun actor Internasional yang lain). Rezim Internasional dipahami sebagai bentuk-bentuk institusionalisasi perilaku yang didasarkan pada norma ataupun aturan untuk mengelola konflik dan masalah-masalah saling ketergantungan di berbagai bidang dalam hubungan Internasional. Stephen D. Krasner mendefinisikan rezim Internasional sebagai seperangkat prinsip-prinsip, norma-norma, aturan-aturan, dan prosedurprosedur pembuatan keputusan baik eksplisit maupun implisit di mana harapan-harapan para aktoraktor yang ada berkumpul dalam sebuah wilayah hubungan tertentu. Rezim Internasional membantu negara-negara untuk konsisten dengan apa yang menjadi tujuan dan ekspektasi mereka dalam menyikapi sebuah isu tertentu karena rezim Internasional sifatnya sangat spesifik dan cenderung hanya berfokus pada satu hal saja. Perjanjian merupakan kesepakatan adhoc, sebaliknya rezim memfasilitasi pembuatan kesepakatankesepakatan substantif dengan memberikan kerangka aturan, norma, prinsip dan prosedur negosiasi.

Berdasarkan ciri-ciri dan sarana yang dimiliki sebagai sebuah rezim 
Internasional, Indonesia dipandang perlu untuk meratifikasi Konvensi 1951 dan Protokol 1967. Keberadaan kedua rezim pengungsi Internasional tersebut dengan berbagaiprinsip, norma, aturan, prosedur serta sarana pelaksanaannya melalui penyusunan standar, alokasi dan larangan, ikut mempengaruhi Indonesia untuk ikut mempertimbangakan ratifikasi rezim pengungsi Internasional tersebut. Hal ini dikarenakan Konvensi 1951 dan Protokol 1967 juga sejalan dengan salah satu tujuan negara yang tertuang dalam alinea ke-empat pembukaan Undang-undang Dasar 1945. Sebagai salah satu anggota PBB, Indonesia secara moral juga ikut bertanggung jawab untuk melaksanakan Pernyataan Umum tentang Hak-Hak Asasi Manusia (Universal Declaration of Human Rights) (Sri Badini Amidjojo;2006). Hak asasi manusia dalam konteks rezim pengungsi Internasional sendiri setidaknya berhubungan dengan tiga hal yaitu perlindungan terhadap penduduk sipil akibat konflik bersenjata, perlindungan secara umum yang diberikan kepada penduduk sipil dalam keadaan biasa, dan perlindungan terhadap pengungsi baik pengungsi internal maupun pengungsi lintas batas.

\section{Keuntungan Indonesia Dalam Meratifikasi Konvensi}

Menurut Komnas HAM jika Indonesia meratifikasinya setidaknya Indonesia mendapat beberapa keuntungan. Keuntungan tersebut seperti pertama, pemerintah dapat menentukan sendiri status para pengungsi dan pencari suaka. Kedua, pemerintah dapat mendapat bantuan dan kerjasama internasional terkait penguatan kapasitas nasional dalam penanganan pengungsi dan pencari suaka. Ketiga, mencegah para pembonceng yang memiliki motif yang berbeda. Pembonceng itu biasanya terkait dengan kegiatan pidana seperti human trafficking

(www.hukumonline.com). Ratifikasi Konvensi Pengungsi 1951 dan Protokol 1967 oleh pemerintah Indonesia sangat penting bagi jaminan penghormatan, pemenuhan, dan perlindungan HAM para pengungsi dan pencari suaka. Di samping itu, upaya meratifikasi instrumen HAM internasional tersebut dapat menjadi solusi atas jalan buntu yang dihadapi pemerintah dalam menangani pengungsi dan pencari suaka yang jumlahnya terus bertambah. Langkah meratifikasi Konvensi Pengungsi 1951 dan Protokol 1967 memberikan kesempatan lebih besar bagi Pemerintah Indonesia untuk terlibat langsung dan berkontribusi sesuai dengan kepentingan nasional dalam penanganan pengungsi dan pencari suaka. Menolak meratifikasi Konvensi Pengungsi 1951 dan Protokol 1967 akan merugikan karena Pemerintah Indonesia tidak dapat menentukan sendiri status pengungsi dan pencari suaka. Keputusan tentang status pengungsi menjadi sangat tergantung pada keputusan UNHCR. Penentuan status oleh pemerintah dapat memastikan bahwa pencarian suaka tidak dijadikan selubung bagi pelarian orang yang terlibat dalam tindak pidana dan kejahatan menurut hukum internasional. Di samping itu, ratifikasi juga meluangkan kesempatan bagi Pemerintah Indonesia untuk memperoleh bantuan dan kerjasama internasional terkait dengan penguatan kapasitas nasional dalam penanganan pengungsi dan pencari suaka.

\section{Simpulan}

Dari penjelasan di atas maka kita telah mengetahui penyebab Indonesia belum meratifikasi Konvensi 1951 dan Protokol 1967 tersebut. Secara rasional kedatangan para pengungsi internasional ini hanya akan menimbulkan gangguan di dalam negeri Indonesia sendiri. 
Gangguan yang ditimbulkan seperti menimbulkan efek kepada ekonomi, sosial dan keamanan potensial. Dari efek ekonomi, kedatangan pengungsi berimbas kepada meningkatakan anggaran Indonesia. Apabila dilihat adari aspek sosial akan menimbulkan masalah ketika proses asimilasi antara penduduk lokal dengan pengungsi internasional tidak berjalan dengan baik. Sedangkan dari segi keamanan, kedatangan pengungsi dianggap sebagai ancaman keamanan bagi Indonesia. Negara akan memikirkan terlebih dahulu keadaan dalam negerinya sebelum menerima warga asing yang menetap di Indonesia. Sehingga Indonesia dapat menjaga kestabilan kehidupan masyarakatnya demi terciptanya keadilan sosial bagi seluruh rakyat Indonesia.

\section{Saran}

Kerjasama internasional akan mendorong penyelesaian masalah pengungsi dan pencari suaka dengan cara yang lebih komprehensif. Dengan demikian, beban penanganan pengungsi dan pencari suaka tidak ditanggung semata-mata oleh pemerintah kita, tetapi juga dukungan komunitas internasional yang bergerak pada isu pengungsi dan pencari suaka.

\section{Daftar Pustaka}

\section{Buku}

Achmad Romsan. 2003. Pengantar Hukum Pengungsi Internasional: Hukum Internasional dan Prinsipprinsip Perlindungan Internasional. Jakarta.

Syahmin. 2008. Hukum Diplomatik dalam Kerangka Studi Analisis. PT. Raja Grafindo Persada.

Sri Badini Amidjojo. 2006. Perlindungan Hukum Terhadap Pengungsi Berdasarkan
Konvensi Jenewa 1951. Jakarta: Badan Pembinaan Hukum Nasional Departemen Kehakiman dan Hak Asasi Manusia RI.

\section{Jurnal}

Krustiyati, Atik. 2008. "Aspek Hukum Internasional Penyelesaian Pengungsi Timor Leste sebagai Upaya Peningkatan Hubungan Bilateral Antara Indonesia dan Timor Leste", Jurnal Yustika, Vol.II, No.1. Surabaya: Universitas 17 Agustus 1945.

Krustiyati, Atik. 2012. "Kebijakan Penanganan Pengungsi Di Indonesia: Kajian dari Konvensi Pengungsi Tahun 1951 Dan Protokol 1967'. Law Review, Volume XII No. 2. Surabaya: Universitas Surabaya

M. Husni Syam. 2009. Perlindungan Internasional Terhadap Pengungsi Dalam Konflik Bersenjata. Jurnal Vol XI No. 1

Ria Rosiana Simbolon. 2004. Penundaan Ratifikasi Konvensi 1951 dan Protokol 1967 Tentang Status Pengungsi Oleh Pemerintah Indonesia. Samarinda: Universitas Mulawarman.

Sigit Riyanto. 2004. "Urgensi Legislasi Hukum Pengungsi dan Kendalanya di Indonesia", Jurnal Hukum Internasional, Vol. 2, No.1.

Sukanda Husin. 1998. UNHCR dan Perlindungan Hak Azasi Manusia. Padang: Fakultas Hukum Univesitas Andalas. No 7 Th. V/ 1998.

\section{Internet}

Ady. Indonesia Perlu Ratifikasi Konvensi Tentang Pengungsi. Diakses dari www.hukumonline.com. Pada 
Volume 1, Nomor 2 Oktober 2019

ISSN : 2656-9639 (Cetak)

ISSN : 2684-9046 (Online)

tanggal 16 Juni 2019, pukul 19.35 WITA.

UNHCR. 2011. Statlis Related to

Refugees. Diakses dari

www.uncr.org, pada tanggal 13

Juni 2019, pukul 13.59 WITA. 